\title{
Path Analysis of Exogenous Variables against Technology Adoption Levels of Dairy Cattle in West Sumatera
}

\author{
Herawati T, Priyanto D \\ Indonesian Research Institue of Animal Production \\ E-mail: herawati_tati@yahoo.com \\ (received 15-02-2017; revised 22-03-2017; accepted 29-03-2017)
}

\begin{abstract}
ABSTRAK
Herawati T, Priyanto D. 2017. Analisis pola variabel eksogen terhadap tingkat adopsi teknologi sapi perah di Sumatera Barat. JITV 22(1): 9-15. DOI: http://dx.doi.org/10.14334/jitv.v22i1.1603

Analisis jalur pada persamaan regresi dapat digunakan untuk melihat pengaruh langsung maupun pengaruh tidak langsung dari beberapa peubah eksogen terhadap peubah endogen. Tingkat adopsi suatu teknologi sebagai peubah endogen dapat dipengaruhi oleh beberapa peubah eksogen, secara langsung maupun tidak langsung. Tujuan penelitian ini adalah untuk menguji beberapa peubah eksogen dari karakteristik usaha sapi perah terhadap tingkat adopsi teknologi pakan sebagai peubah endogen, melalui penelusuran jalur. Pada tahun 2016, dilakukan penelitian di kota Padang Panjang, Sumatera Barat khususnya pada kelompok peternak sapi perah. Peubah endogen dalam hal ini adalah tingkat adopsi teknologi pakan (Z). Peubah eksogen adalah tingkat pendidikan (X1), usia peternak (X3), jumlah sapi laktasi (X2), skala usaha (Y1) dan produksi susu (Y2). Dua peubah terakhir adalah sebagai peubah tengah, yakni yang menjembatani pengaruh tidak langsung. Diperoleh hasil bahwa hanya peubah usia peternak (X3) yang mempunyai pengaruh langsung terhadap $Z$, dengan nilai $\rho_{Z x 3}=0,834$ dan $P=0,018$. Peubah lainnya yaitu $\mathrm{X} 1$ dan $\mathrm{X} 2$, berpengaruh signifikan terhadap $\mathrm{Y} 1$, dan $\mathrm{X} 2$ berpengaruh terhadap $\mathrm{Y} 2$ dengan nilai koefisien jalur berturut-turut $\rho_{\mathrm{y} 1 \times 1}=0,133$ dan $\mathrm{P}=0,040 ; \rho_{\mathrm{y} 1 \times 2}=0,982$ dan $\mathrm{P}=0,000 ; \rho_{\mathrm{y} 2 \mathrm{x} 2}=0,841$ dan $\mathrm{P}=0,008$. Oleh karena itu tidak ada kerangka hubungan kausal empiris bersama antara peubah $X$ dan $Y$ terhadap $Z$, hanya parsial dari X3 dengan struktur model $Z=\rho Z \times 3 X 3+\rho Z \varepsilon 2=$ $0,834 \mathrm{X} 3+0,217 \varepsilon_{2}$. Disimpulkan bahwa usia peternak sangat mempengaruhi adopsi teknologi pakan sapi perah, semakin tua usia peternak maka semakin sulit untuk adopsi teknologi yang direkomendasikan.
\end{abstract}

Kata Kunci: Analisa Jalur, Sapi Perah, Adopsi Teknologi Pakan

\section{ABSTRACT}

Herawati T, Priyanto D. 2017. Path analysis of exogenous variables against technology adoption levels of dairy cattle in West Sumatera. JITV 22(1): 9-15. DOI: http://dx.doi.org/10.14334/jitv.v22i1.1603

Path analysis of the regression equation can be used to see the direct and also indirect influence of some exogenous variables against endogenous variables. The rate of feed technology adoption as an endogenous variables can be directly or indirectly influenced by some exogenous variables. The purpose of this research was to test multiple exogenous characteristics variables of dairy cows farms against the feed technology adoption rate as endogenous variables, through path analysis. Research conducted in the city of Padang Panjang, West Sumatra in particular farmer group of dairy cattle in 2016. Endogenous variable is the level of adoption of feed technology $(\mathrm{Z})$. Whereas the exogenous variables are the level of education $\left(\mathrm{X}_{1}\right)$, the age of farmer $\left(\mathrm{X}_{3}\right)$, the amount of cow's lactation $\left(\mathrm{X}_{2}\right)$, farm scale $\left(\mathrm{Y}_{1}\right)$ and milk production $\left(\mathrm{Y}_{2}\right)$. The last two variables are variables which are bridging the influence indirectly. Obtained results showed that only $\mathrm{X}_{3}$ which directly influenced $\mathrm{Z}$, with a value of $\rho \mathrm{Zx} 3=0.834$ and $\mathrm{P}=$ 0.018. Other variables $X_{1}$ and $X_{2}$ partly significantly influenced $Y_{1}$ and $X_{2}$ significantly influenced $Y_{2}$ with value of path coefficient in successively $\rho_{y 1 \times 1}=0.133$ and $\mathrm{P}=0.040 ; \rho_{\mathrm{y} 1 \times 2}=0.982$ and $\mathrm{P}=0.000 ; \rho_{\mathrm{y} 2 \times 2}=0.841$ and $\mathrm{P}=0.008$. Therefore, there was no special model of causal relationships between the empirical variables $\mathrm{X}$ and $\mathrm{Y}$ against $\mathrm{Z}$, except the $\mathrm{X}_{3}$ which had structure model $Z=\rho Z x_{3} \mathrm{X}_{3}+\rho_{\varepsilon \varepsilon 2}=0.834 \mathrm{X}_{3}+0.217 \varepsilon_{2}$. It was concluded that the age strongly influenced the feeding technology adoption. The older the age of farmers, the more difficult for adopting recommended technology.

Key Words: Path Analysis, Dairy Cattle, Feed Technology Adoption

\section{INTRODUCTION}

Dairy cattle farming, currently still concentrated in the Java Island, even though the dairy consumers spread evenly around Indonesia. Fresh milk production in Indonesia is concentrated in Java Island (95\%) with negative total net export-import trading (Hasan 2016; Farid \& Sukesi 2017). The efficiency is an obstacle of
Indonesian fresh milk production in the outside of Java Island. This as shown by milk production data in 2000, which showed 6,420 dairy cows in North Sumatera producing 4,615 ton fresh milk, meanwhile in West Java with 84,788 dairy cows were able to produce 184,515 ton fresh milk (Yusdja et al. 2016). In 2016 the population of dairy cows in Indonesia, increased up to 533,860 (BPS 2016). Therefore, the improvement 
efficiency of rearing dairy cow, in Java Island is crucial in order to fullfil National fresh milk demand.

The government, through policies package and programs of provincial services, has attempted to improve productivity and income of dairy cattle farmers. The policy of Milk Processing Industry, which obliges to buy domestic milk, is one example policy to protect dairy cattle farmers (Budiyono 2012). Indonesian Agency for Agricultural Research and Development (IAARD), through the technical implementation units has developed feed technology to support the increase of national dairy cattle productivity (Mathius 2014; Ginting \& Elisabeth 2014; Adnyana \& Mardianto 2016). However, the productivity of dairy cattle in the outside Java Island reminds low (Yusdja 2017; Diwyanto et al. 2017). From the point of view of technology introduction, it is allegedly that technology of dairy cattle production introduced, cannot be adopted well in a location. Not optimal adoption of the technology may be induced by ineffective adoption method (Nugroho et al. 2014; Nuryanti \& Swastika 2016).

Factors affecting adoption of dairy cattle technology consist of exogenous and endogenous factors of user. The exogenous factors are farm scale; the amount of cow's lactation and milk production, meanwhile the endogenous factors are level of education and age of the farmers which help determine attitude and level of understanding of the technologies introduced. Study of correlation factors should be conducted to optimize the adoption, since the interaction between factors may be specific both for the commodity or the location (Sudaryanto \& Agustian 2017). That is underlying this study conducted.

This study was aimed to test multiple exogenous characteristics variables of dairy cows farms against the feed technology adoption rate as endogenous variables, through path analysis. Research conducted in the city of Padang Panjang, West Sumatra in particular farmer groups of dairy cattle. This location has good potential in dairy cattle development supported by suitable agroclimate, feed source availability and independence level of farmers. The city of Padang Panjang is well known as the biggest agribusiness region of dairy cattle in the
West Sumatera (Sartika \& Rahmi 2012). Meanwhile, quantification of technology adoption correlation factor $r$ was conducted by assessing that correlation factors through path analysis. This model may be used to find out the direct and also indirect effects on several factors reflected on path coefficient value following structural model mathematically (Trinayani et al. 2013; Azis \& Kamal 2017). The understanding of this correlation factors will optimize introduction and adoption process of feed technology of dairy cattle.

\section{MATERIALS AND METHODS}

Research conducted in the city of Padang Panjang, West Sumatra in particular farmer group of dairy cattle in 2016. This study used quantitative and qualitative approaching through structured survey. The respondents were four dairy cattle farmer groups and one individual farmer (Table 1).

Data analyzed were the age of farmer (year), the level of education of farmer (year), the amount of cow's lactation (head), farm scale (head), milk production (litter/day) and adoption rate (score: 1-4).

The narrative descriptive analysis was used as qualitative analysis model. Quantitative analysis model was performed in the main basis of path analysis model consisting of exogenous (level of education, the age of farmer, the amount of cow's lactation, farm scale and milk production) and endogenous (level of adoption of feed technology) variables with two hypotheses tested:

1. First hypothesis and structural formulation model $\mathrm{H}_{0}: \rho_{\mathrm{Zx} 1}=\rho_{\mathrm{Zx} 2}=\rho_{\mathrm{Zy} 1}=0 \quad$ vs $\quad \mathrm{H}_{1}: \rho_{\mathrm{Zx} 1}=\rho_{\mathrm{Zx} 2}=\rho_{\mathrm{Zy} 1} \neq 0$ Hypothesis: Level of education $\left(\mathrm{X}_{1}\right)$, Amount of lactating cows $\left(\mathrm{X}_{2}\right)$ and farm scale $\left(\mathrm{Y}_{1}\right)$ contributed simultaneously to adoption rate of feed technology (Z).

First structure model and path coefficient shape

2. Second hypothesis and structural formulation model $H_{0}: \rho_{Z x 3}=\rho_{Z x 2}=\rho_{Z y 2}=0 \quad$ vs $\quad H_{1}: \rho_{Z x 3}=\rho_{Z x 2}=\rho_{Z y 2} \neq 0$ Hypothesis: Age of farmers $\left(\mathrm{X}_{3}\right)$, Amount of lactating cows $\left(\mathrm{X}_{2}\right)$ and Milk production $\left(\mathrm{Y}_{2}\right)$ contributed simultaneously to adoption rate of feed technology $(\mathrm{Z})$.

Second structure model and path coefficient shape

Table 1. Respondents of the survey in the city of Padang Panjang.

\begin{tabular}{lllc}
\hline \hline Name & \multicolumn{1}{c}{ District } & \multicolumn{1}{c}{ Sub-District } & The Number of Member (persons) \\
\hline Serambi Karya Mandiri & Koto Katiak & East Padang Panjang & 9 \\
Harapan Baru & Ganting & East Padang Panjang & 12 \\
Parmato Mudo Nagari & Silang Bawah & West Padang Panjang & 7 \\
Makmur Batu Batire & Kampung Manggis & West Padang Panjang & 10 \\
Rafles (individual farmer) & Kampung Manggis & West Padang Panjang & 1 \\
\hline
\end{tabular}




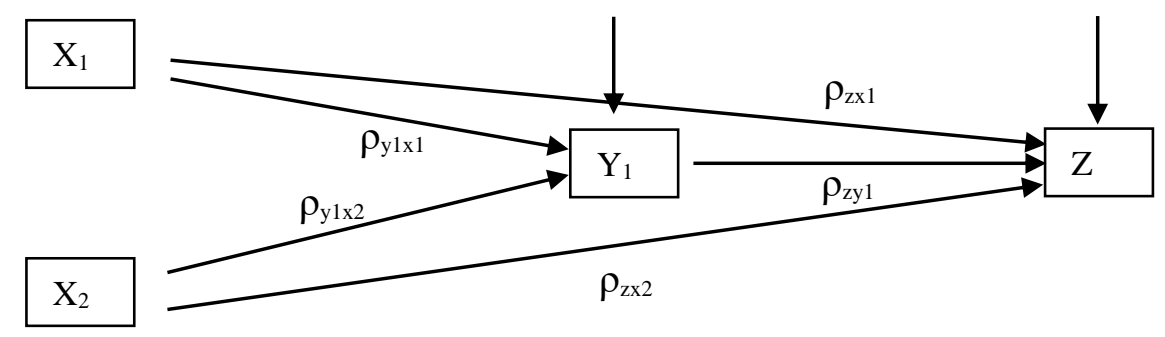

$$
Y_{1}=\rho_{y 1 x 1} X_{1}+\rho_{y 1 \times 2} X_{2}+\varepsilon_{1} \ldots \ldots . .(1) \text { and } Z=\rho_{z y 1} Y 1+\varepsilon_{2}
$$

Direct effect of exogenous variables $\left(\mathrm{X}_{1}\right.$ and $\left.\mathrm{X}_{2}\right)$ to endogenous variable $\left(\mathrm{Y}_{1}\right)$ and indirectly to $\mathrm{Z}$ variable with $\boldsymbol{\varepsilon}_{1}$ error.

Direct effect of $\mathrm{Y}_{1}$ variable to $\mathrm{Z}$ variable with $\varepsilon_{2}$ error.

1

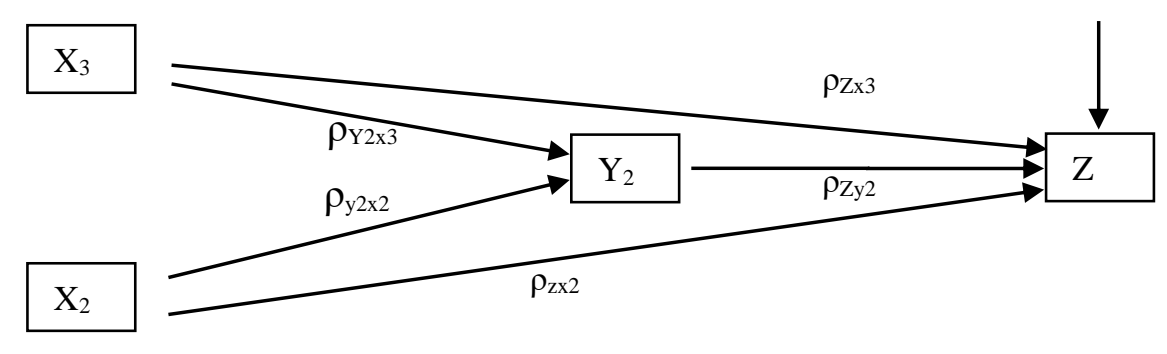

$$
Y_{2}=\rho_{y 2 \times 3} X_{3}+\rho_{y 2 \times 2} X_{2}+\varepsilon_{3} \ldots \ldots \ldots . . .(3) d a n Z=\rho_{z y 2} Y_{2}+\varepsilon_{4}
$$

(1) Direct effect of exogenous variables $\left(\mathrm{X}_{3}\right.$ and $\left.\mathrm{X}_{2}\right)$ to endogenous variable $\left(\mathrm{Y}_{2}\right)$ and indirectly to $\mathrm{Z}$ variable with $\varepsilon_{3}$ error.

Direct effect of $Y_{2}$ variable to $Z$ variable with $\varepsilon_{4}$ error.

\section{RESULTS AND DISCUSSION}

\section{Testing result of the first model}

Simultaneous effect of education level, amount of cows lactation and farm scale to the adoption rate of feed technology, which was notified as $Z=f\left(X_{1}, X_{2}\right.$, $\left.\mathrm{Y}_{1}\right)$.

This model was motivated by field condition that generally, the large-scale business willing to adopt the technologies introduced. The increase of the number of lactation cow lead to the desire to expand the business scale and to increase milk production. It surely would increase farmer's income. Education level had positive correlation to the adoption rate of technology (Shiferaw et al. 2015; Saridewi \& Siregar 2016).

The result of path tracking analysis to test variable: education $\left(\mathrm{X}_{1}\right)$, amount of lactating cows $\left(\mathrm{X}_{2}\right)$ and farm scale $\left(\mathrm{Y}_{1}\right)$ simultaneously, contributed to the adoption rate of feed technology $(\mathrm{Z})$, showed that $\mathrm{R}^{2}$ and probability value by 0.086 and $0.921>5 \%$, respectively

(Table 2). Therefore, the $H_{0}: \rho_{z x 1}=\rho_{z x 2}=\rho_{z y 1}=0$ was accepted. This meant that there was no direct effect from the $X_{1}$ and $X_{2}$ variables against the $Z$ and indirect effect that was through the $Y_{1}$. In consequence, the test was continued for partial test of the $X_{1}$ and $X_{2}$ variables against $Y_{1}$. The partial test resulted $R^{2}$ and $F$ value by

Table 2. Testing result of direct effect model

\begin{tabular}{lcccc}
\hline \hline Model & R Square & Std. Error of the Estimate & F Change & Sig. F Change \\
\hline 1 & 0.086 & 0.907 & 0.156 & 0.921 \\
\hline
\end{tabular}

a) Predictors: (Constant), Education $\left(\mathrm{X}_{1}\right)$, Lactation Cow $\left(\mathrm{X}_{2}\right)$, Farm Scale $\left(\mathrm{Y}_{1}\right)$

b) Dependent Variable: Adoption of Technology (Z) 
Table 3. Coefficients of the first partial path model (1)

\begin{tabular}{lccccc}
\hline \hline \multirow{2}{*}{ Model } & \multicolumn{2}{c}{$\begin{array}{c}\text { Unstandardized } \\
\text { Coefficients }\end{array}$} & $\begin{array}{c}\text { Standardized } \\
\text { Coefficients }\end{array}$ & $\mathrm{t}$ & Sig. \\
\cline { 2 - 6 } & $\mathrm{B}$ & Std. Error & Beta & -1.089 & 0.318 \\
(Constant) & -1.857 & 1.705 & & 2.607 & 0.040 \\
X1.Education & 1.698 & 0.651 & 0.133 & 19.902 & 0.000 \\
X2.Lactating Cow & 1.891 & 0.095 & 1.016 & & \\
\hline
\end{tabular}

a Dependent Variable: Farm Scale $\left(\mathrm{Y}_{1}\right)$

0.985 and 200.399 , respectively with probability value by $0.00<5 \%$ showed that the $\mathrm{X}_{1}$ and $\mathrm{X}_{2}$ simultaneously contributed against the $\mathrm{Y}_{1}$. That meant the $\mathrm{H} 0: \rho_{\mathrm{y} 1 \mathrm{x} 1}=$ $\rho_{\mathrm{y} 1 \mathrm{x} 2}=0$ was rejected and the alternative hypothesis, $\mathrm{H} 1$ $: \rho_{\mathrm{y} 1 \times 1}=\rho_{\mathrm{y} 1 \times 2} \neq 0$ was accepted with the value presented in Table 3 .

Path coefficient value of the partial test was $\rho_{\mathrm{y} 1 \mathrm{x} 1}=$ 0.133 with lower significance value by 0.040 than the probability value by 0.05 . That meant that the $\mathrm{H}_{0}: \rho_{\mathrm{y} 1 \mathrm{x} 1}=0$ was rejected or the $\mathrm{H}_{1}: \rho_{\mathrm{y} 1 \mathrm{x} 1} \neq 0$ was accepted. It also meant that the education contributed to the farm scale level. Then the value of $\rho_{\mathrm{y} 1 \times 2}=1.016$ with significance level by 0.00 showed that the number of lactation cow was significantly affected by the farm scale. The higher education and number of lactation cow increased the willingness to increase the farm scale. Education level might have changed the mindset, even better reasoning, so it might hve been concluded that higher education level leading someone to be more rational (Narti 2016), for a better mindset resulting in a better management for their agribusiness (Ruggiero et al. 2017; Kumaran et al. 2017). Even the value showed the contribution of education level to the farm scale, as a result of the willingness to expand their business, in this study, showed there was no direct correlation between the farm scales with the adoption rate of technology. It seemed that the correlation test of the adoption rate of technology to the farm scale needed to be carried out as staed by the Rosandy et al. (2012) that one attempt to expand the business scale was improvement and adoption of the technologies. At the same time, the acceptance of information technology (IT) required special efforts. The low rate of IT adoption was influenced by many factors that the most were from the internal. Those factors were social, institutional and financial (Fauzi et al. 2017; Suhaeti \& Suharni 2017; Yuwono 2017).

From the test results above, causal-empiric correlation framework between the $\mathrm{X}_{1}$ and $\mathrm{X}_{2}$ to $\mathrm{Y}_{1}$ might have been formed as the following formulas:

$$
\begin{aligned}
& Y_{1}=\rho_{\mathrm{y} 1 \times 1} X_{1}+\rho_{\mathrm{y} 1 \times 2} X_{2}+\varepsilon_{1} \\
& Y_{1}=0,133 X_{1}+1,016 X_{2}+\rho_{\mathrm{y} 1} \varepsilon_{1} . \\
& \rho_{\mathrm{y} 1}(\text { remind variable })=1-\mathrm{R}^{2}=1-0,985=0,015 \\
& Y_{1}=0,133 \mathrm{X}_{1}+1,016 \mathrm{X}_{2}+0,015 \varepsilon_{1} .
\end{aligned}
$$

\section{Testing result of the second model}

The simultaneous effect of age, amount of lactation cow and milk production against the adaptation of feed technology, was noted as $Z=f\left(X_{2}, X_{3}, Y_{2}\right)$.

The result of path tracking analysis to test variables: age $\left(\mathrm{X}_{3}\right)$, amount of lactation cow $\left(\mathrm{X}_{2}\right)$ and milk production $\left(\mathrm{Y}_{2}\right)$, showed a weak contribution $(\mathrm{P}=8 \%)$ to the adoption rate of feed technology $(\mathrm{Z})$ (Table 4$)$. The path coefficient tracking result showed that the age $\left(\mathrm{X}_{3}\right)$ affected directly to the adoption rate of feed technology with the path coefficient and significance level value by -0.843 and $18 \%$, respectively. Whereas, the other factors were not significantly affected the $Z$ (Table 5). The negative value of the coefficient $\rho_{\mathrm{zx} 3}$ showed an inverse correlation of the age to the technology adoption rate. This indicated that the older farmer the less the interest in adopting the recommended technologies. Young stakeholders were more interested in the new technologies which meant that age was a significant effect (Gyau et al. 2014).

The partial test of the $\mathrm{X}_{2}$ and $\mathrm{X}_{3}$ to the $\mathrm{Y}_{2}$ resulted in the $\mathrm{R}^{2}=0.722 ; \mathrm{F}=7.807$ and was significant at the level of $2.1 \%$. But, it was only the amount of lactating cows affecting milk production with value of $\rho_{\mathrm{y} 2 \times 2}=$ 0.841 and with significance by 0.008 (Table 6).

From this study result, it was expected to be a basis of selection of the target characteristics to improve the adoption rate of technology. Considering that technology adoption was expected to provide significant correlation to improve the productivity and increase the population of livestock. Besides, effective socialization was required to deliver better understanding and build the willingness to adopt the technologies. 
Table 4. Testing result of direct effect model

\begin{tabular}{lcccc}
\hline \hline Model & R Square & Std. Error of the Estimate & F Change & Sig. F Change \\
\hline 2 & 0.713 & 0.508 & 4.149 & 0.080 \\
\hline
\end{tabular}

a Predictors: (Constant), Age of farmers $\left(\mathrm{X}_{3}\right)$, Lactating Cow $\left(\mathrm{X}_{2}\right)$, Milk Production $\left(\mathrm{Y}_{2}\right)$

b Dependent Variable: Adoption of Technology (Z)

Table 5. Coefficient value of direct path toward Z (2)

\begin{tabular}{lccccc}
\hline \multirow{2}{*}{ Model } & \multicolumn{2}{c}{ Unstandardized Coefficients } & Standardized Coefficients & $\mathrm{t}$ & \multicolumn{2}{c}{ Sig. } \\
\cline { 2 - 6 } & $\mathrm{B}$ & Std. Error & Beta & $\mathrm{B}$ & Std. Error \\
\hline (Constant) & 6.395 & 0.967 & & 6.610 & 0.001 \\
X $_{2}$ Lactating Cow & 0.027 & 0.049 & 0.244 & 0.542 & 0.611 \\
Y2.Milk Production & -0.001 & 0.005 & -0.142 & -0.312 & 0.768 \\
X3.Age & -0.077 & 0.022 & -0.834 & -3.439 & 0.018 \\
\hline
\end{tabular}

Dependent Variable: Adaptation of Technology (Z)

Table 6. Coefficient value of partial path toward $\mathrm{Y}_{2}(2)$

\begin{tabular}{lccccc}
\hline \hline \multirow{2}{*}{ Model } & \multicolumn{2}{c}{ Unstandardized Coefficients } & Standardized Coefficients & $\mathrm{t}$ & Sig. \\
\cline { 2 - 5 } & $\mathrm{B}$ & Std. Error & Beta & $\mathrm{B}$ & Std. Error \\
\hline (Constant) & 39.794 & 83.201 & & 0.478 & 0.649 \\
X $_{3}$. Age of farmers & -0.705 & 1.936 & -0.078 & -0.364 & 0.728 \\
X $_{2}$.lactating cow & 8.971 & 2.300 & 0.841 & 3.900 & 0.008 \\
\hline
\end{tabular}

Dependent Variable: Milk Production $\left(\mathrm{Y}_{2}\right)$

Table 7. The Value of path coefficient

\begin{tabular}{|c|c|c|c|c|c|}
\hline \multicolumn{2}{|l|}{ Variable } & \multicolumn{2}{|c|}{ Testing Result } & \multicolumn{2}{|l|}{ Value } \\
\hline Endogenous & Exogenous & $\mathrm{R}^{2}$ & $\mathrm{P}$ & Standardized Coefficients $\rho_{\text {End.Ex }}$ & Sig. \\
\hline \multirow{3}{*}{$\mathrm{Z}$} & $\mathrm{X} 1$ & \multirow{3}{*}{0.086} & \multirow{3}{*}{0.921} & 0.156 & ns \\
\hline & $\mathrm{X} 2$ & & & 0.244 & ns \\
\hline & Y1 & & & 0.131 & ns \\
\hline \multirow{2}{*}{ Y1 } & $\mathrm{X} 1$ & \multirow{2}{*}{0.985} & \multirow{2}{*}{$0.000 * *$} & 0.133 & $* *$ \\
\hline & $\mathrm{X} 2$ & & & 0.982 & $* *$ \\
\hline \multirow{3}{*}{$\mathrm{Z}$} & $\mathrm{X} 2$ & \multirow{3}{*}{0.713} & \multirow{3}{*}{0.080} & 0.244 & ns \\
\hline & $\mathrm{X} 3$ & & & -0.834 & $* *$ \\
\hline & $\mathrm{Y} 2$ & & & 0.142 & ns \\
\hline \multirow{2}{*}{ Y2 } & $\mathrm{X} 2$ & \multirow{2}{*}{0.722} & \multirow{2}{*}{$0.021 * *$} & 0.841 & $* *$ \\
\hline & X3 & & & 0.078 & ns \\
\hline
\end{tabular}




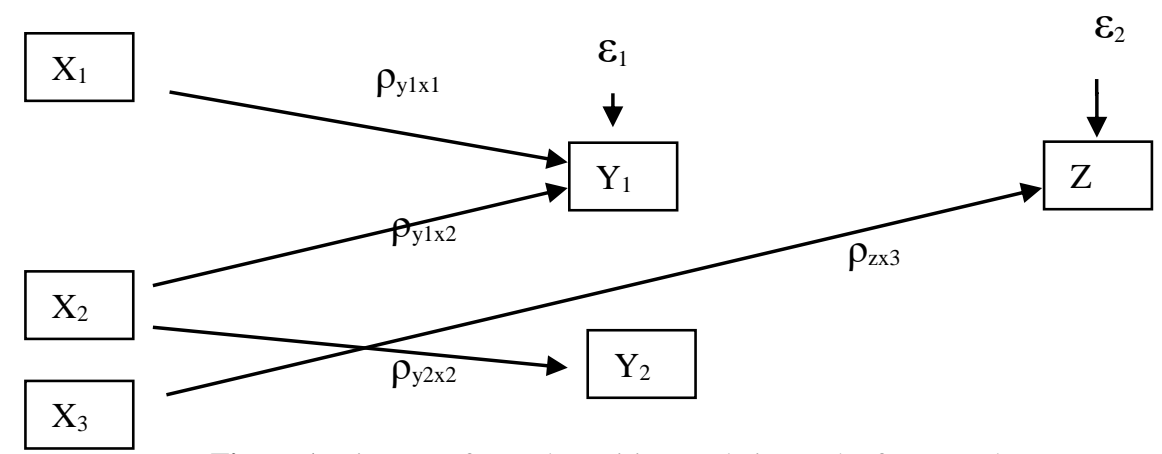

Figure 1. Diagram of causal-empiric correlation path of $\mathrm{X}, \mathrm{Y}$ and $\mathrm{Z}$.

\section{CONCLUSION}

The study concluded that only age of farmers that had direct effect to the adoption rate of feed technology. The older the age of farmers the more difficult for adopting recommended technology. Education and the amount of lactation cow significantly affected the farm scale. The higher education and the greater number of lactating cows the higher willingness of farmer.

\section{REFERENCES}

Azis E, Kamal RM. 2017. Adopsi Teknologi belanja online konsumen UMKM dengan Model Unified Theory of Acceptance and Use of Technology. Creative Res J. 2:19-38.

Adnyana MO, Mardianto S. 2016. Dampak era globalisasi ekonomi terhadap usaha ternak sapi perah: Kajian Peluang, kendala dan strategi pengembangan. J Agro Ekonomi. 15:54-75.

[BPS] Badan Pusat Statistik. 2016. Populasi sapi perah menurut propinsi tahun 2009-2016. Jakarta (Indones). Badan Pusat Statistik.

Budiyono H. 2012. Analisis harga, impor dan ekspor susu. J LPPM: PARADIGMA. 9:207-212.

Diwyanto K, Priyanti A, Saptati RA. 2017. Prospek pengembangan usaha peternakan pola integrasi. J Penelitian Ilmu Peternakan. 5:26-33.

Farid M, Sukesi H. 2017. Pengembangan susu segar dalam negeri untuk pemenuhan kebutuhan susu nasional. Buletin Ilmiah Litbang Perdagangan. 5:196-221.

Fauzi A, Suharjo B, Syamsun M. 2017. Pengaruh sumber daya finansial, aset tidak berwujud dan keunggulan bersaing yang berimplikasi terhadap kinerja usaha mikro, kecil dan menengah di Lombok NTB. J Manajemen Pengembangan Industri Kecil Menengah. 11:151-158.

Ginting SP, Elisabeth J. 2014. Teknologi pakan berbahan dasar hasil sampingan perkebunan kelapa sawit. JITV. 19:227-233.
Gyau A, Smoot K, Kouame C, Diby L, Kahia J, Ofori D. 2014. Farmer attitudes and intentions towards trees in cocoa (Theobroma cacao L.) farms in Côte d'Ivoire. Agroforestry Systems. 88:1035-1045.

Hasan F. 2016. Evaluasi kebijaksanaan industri persusuan di Indonesia. J Agro Ekonomi. 12:48-65.

Kumaran M, Anand PR, Kumar JA, Ravisankar T, Paul J, Vimala DD, Raja KA. 2017. Is Pacific white shrimp (Penaeus vannamei) farming in India is technically efficient?-A comprehensive study. Aquaculture. 468:262-270.

Mathius IW. 2014. Inovasi teknologi pakan berbasis produk samping industri kelapa sawit. JITV. 19:9-24.

Narti S. 2016. Hubungan karakteristik petani dengan efektivitas komunikasi penyuluhan pertanian dalam program SL-PTT (Kasus Kelompok Tani di Kecamatan Kerkap Kabupaten Bengkulu Utara). J Professional FIS UNIVED. 2:40-52.

Nugroho E, Azizah S. 2014. Manajemen komunikasi pembinaan pelestarian plasma nutfah Sapi Rambon di Banyuwangi. J Ilmu-ilmu Peternakan. Univ Brawijaya J. 24:84-95.

Nuryanti S, Swastika DKS. 2016, August. Peran kelompok tani dalam penerapan teknologi pertanian. Forum Penelitian Agro Ekonomi. 29:115-128.

Rosandy RA, Putri SA, Santoso I. 2012. Analisis variabelvariabel yang mempengaruhi tingkat adopsi teknologi dengan metode Partial Least Square (Studi kasus pada sentra industri tahu Desa Sendang, Kec. Banyakan, Kediri). J Teknologi Manajemen AgroIndustri. 1:147-158.

Ruggiero S, Pieragostini E, Rubino G, Petazzi F. 2017. Impact of Mycobacterium avium subspecies paratuberculosis on profit efficiency in semi-extensive dairy sheep and goat farms of Apulia, southern Italy. Prev Vet Med. 136:5664.

Saridewi TR, Siregar AN. 2016. Hubungan antara peran penyuluh dan adopsi teknologi oleh petani terhadap peningkatan produksi padi di Kabupaten Tasikmalaya. J Penyuluhan Pertanian. 5:55-61. 
Sartika W, Rahmi E. 2012. Perkembangan populasi ternak besar dan unggas pada kawasan agribisnis peternakan di Sumatera Barat. Jl Peternakan Indonesia 14:466-472.

Shiferaw B, Kebede T, Kassie M, Fisher M. 2015. Market imperfections, access to information, and technology adoption in Uganda: challenges of overcoming multiple constraints. Agric Econom. 46:475-488.

Sudaryanto T, Agustian A. 2017. Peningkatan daya saing usaha tani padi: Aspek kelembagaan. Analisis Kebijakan Pertanian. 1:255-274.

Suhaeti RN, Suharni S. 2017. Inkorporasi perspektif gender dalam pengembangan rekayasa alat dan mesin pertanian (Alsintan). Analisis Kebijakan Pertanian. 2:67-76.
Trinayani NN, Wandia IN, Puja IK. 2013. Asosiasi Keragaman lokus DNA Mikrosatelit DRB3 gen bola dengan berat badan induk dan berat lahir pedet pada sapi Bali. J Ilmu Kesehatan Hewan. 1:58-63.

Yusdja Y, Ilham N, Sejati WK. 2016. Profil dan permasalahan peternakan. Forum Penelitian Agro Ekonomi. 21:44-56.

Yusdja Y. 2017. Kebijakan ekonomi industri agribisnis sapi perah di Indonesia. Analisis Kebijakan Pertanian. 3:256-268.

Yuwono DM. 2017. Pengarusutamaan gender dalam pembangunan pertanian: Kasus pada pelaksanaan program feati di Kabupaten Magelang. SEPA J Sosial Ekonomi Pertanian Agribisnis. 10:140-147. 